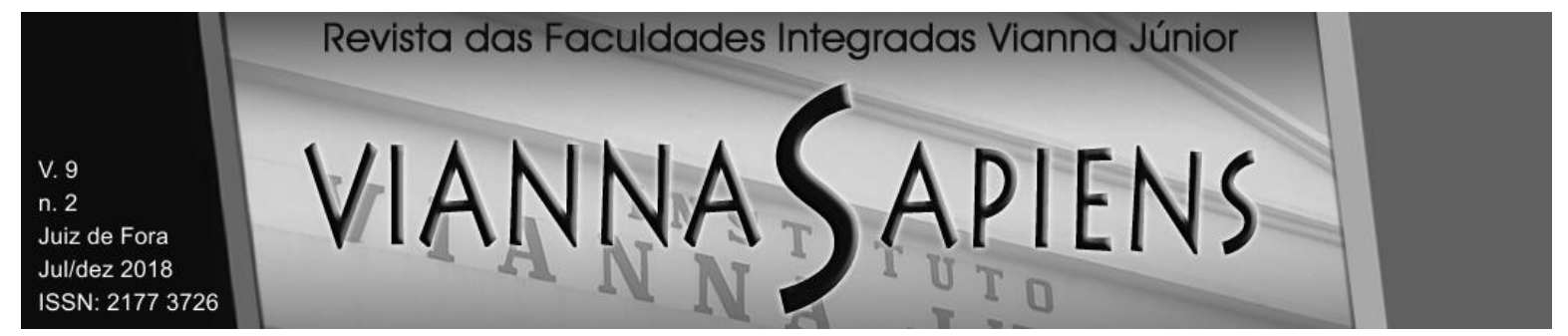

\title{
O FENÔMENO DO SUPERENDIVIDAMENTO NO ORDENAMENTO JURÍDICO
}

BRASILEIRO: soluções legais para o amparo do consumidor superendividado. DOI: 10.31994/RVS.V9I2.425

Edson Camara de Drummond Alves Junior ${ }^{1}$

\section{RESUMO}

Ocorre, atualmente, em todos os países, o fenômeno do "superendividamento", situação essa em que a pessoa física detém dívida superior à sua renda e/ou patrimônio, sendo o objetivo deste trabalho demonstrar que a concessão indiscriminada do crédito pelas instituições financeiras, a vulnerabilidade do consumidor brasileiro e a maior circulação de bens de consumo, no passado, está relacionada com 0 atual superendividamento dos consumidores, apontando instrumentos, em nosso ordenamento jurídico, capazes de proteger, minimamente, a dignidade de todo aquele que estiver nesta condição dramática, utilizando-se, para isso, de uma pesquisa descritiva, aplicada e documental (com emprego da lição de doutrinadores e legislação concernente ao assunto).

PALAVRAS-CHAVE: SUPERENDIVIDAMENTO. CONSUMIDOR. DIGNIDADE DA PESSOA HUMANA.

\footnotetext{
${ }^{1}$ Especialista em Direito Civil e Processual Civil pela Universidade Candido Mendes (UCAM/RJ) e MBA Executivo em Gestão e Business Law pela Fundação Getulio Vargas (FGV/RJ). Advogado (OAB/MG 109.987) e professor de Direito Processual Civil no curso de Direito da Universidade Vale do Rio Verde (UNINCOR/MG). ORCID ID: <https://orcid.org/0000-0001-5817-153X>.
} 


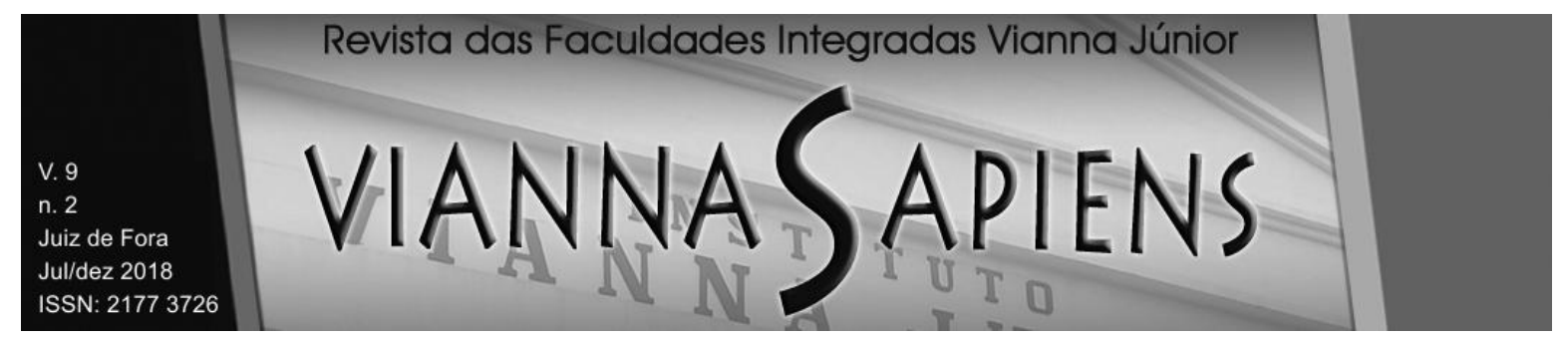

THE PHENOMENON OF OVER-INDEBTNESS IN THE BRAZILIAN LAW: legal solutions to protect the over-indebted consumer.

\begin{abstract}
The phenomenon of "over-indebtness" occurs in all countries, where the individual has a higher debt than his/her income and/or equity. The purpose of this paper is to demonstrate that the indiscriminate concession of credit by financial institutions, the vulnerability of the brazilian consumer and the greater circulation of consumer goods in the past is related to the current over-indebtedness of consumers, pointing to instruments in our legal system capable of minimally protecting the dignity of everyone who is in this dramatic condition, using a descriptive, applied and documentary research (using the lesson of authors and legislation concerning the subject).
\end{abstract}

\title{
KEYWORDS: OVER-INDEBTNESS. CONSUMER. DIGNITY OF HUMAN PERSON.
}

\section{INTRODUÇÃO}

Durante anos, diante de uma economia pulsante e o mercado brasileiro contagiado pelo bom momento vivido internamente, em comparação a outros países que vivenciavam uma crise de natureza global, as instituições financeiras, em nosso território, concediam de maneira fácil, ilimitada e indistintamente, crédito, por meio de, entre outros, empréstimos pessoais, consignados, crédito direto e cheque especial aos consumidores, funcionando como um vetor de crescimento econômico interno e instrumento de acessibilidade aos bens de consumo por estratos sociais que não tinham condições, anteriormente, de desfrutar de todas as benesses de 


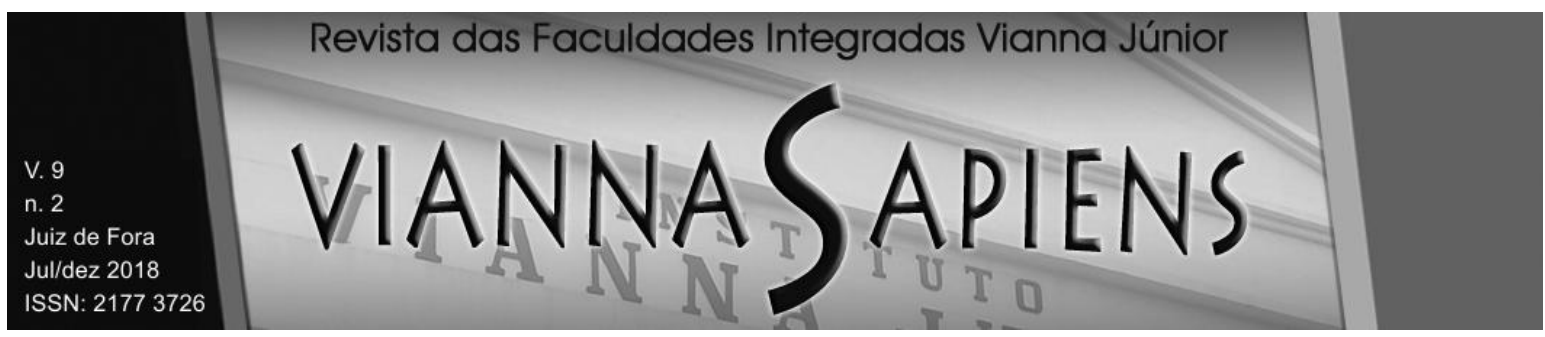

nossa sociedade de consumo, em uma medida de política pública, com o fito de ascensão dos mesmos à classe média.

Porém, passado esse momento de euforia, as consequências desta concessão indiscriminada de crédito e utilizada, em muitos casos, de maneira não consciente e com gastos que não agregam qualquer valor econômico ao rendimento familiar (sem um acompanhamento de receita correspondente), começam a surgir em nosso cotidiano, haja vista a grave crise econômica pela qual passamos, principalmente, materializada no Poder Judiciário, onde o número de pessoas que ingressam com ações para pedir a revisão contratual decorrente de uma relação de consumo, com fundamento no endividamento exacerbado, aumenta e que vem, por isso, chamando a atenção da doutrina brasileira vinculada à defesa do consumidor, que clama por um tratamento legal específico do tema "superendividamento".

O objetivo deste trabalho é demonstrar que a concessão indiscriminada do crédito pelas instituições financeiras, a vulnerabilidade do consumidor brasileiro e a maior circulação de bens de consumo, no passado, está relacionada com o superendividamento dos consumidores, atualmente, constituindo um dos principais problemas da sociedade de consumo em massa contemporânea e depois de concluída, a pesquisa será capaz de verificar se há instrumentos, em nosso ordenamento jurídico, capazes de proteger, minimamente, a dignidade de todo aquele que estiver nesta condição dramática (e que não a motivou), assim como a própria coletividade (indiretamente) a qual está inserido, utilizando-se, para isso, de uma pesquisa descritiva, bibliográfica e documental (com emprego da lição de doutrinadores e legislação concernente ao assunto), analisando-se, para isso, a própria sociedade consumista contemporânea, o mercado consumidor e o papel do crédito no Brasil, destacando-se o crescimento do endividamento em nossa comunidade, decorrente, principalmente, do trabalho de marketing e de uma lógica capitalista; além disso, estudar-se-á, detidamente, o fenômeno "superendividamento", apresentando-se o seu conceito doutrinário e as suas causas, assim como o perfil, as espécies de superendividados e a previsão legal da proteção do vulnerável consumidor que se encontra nesta situação delicada. 


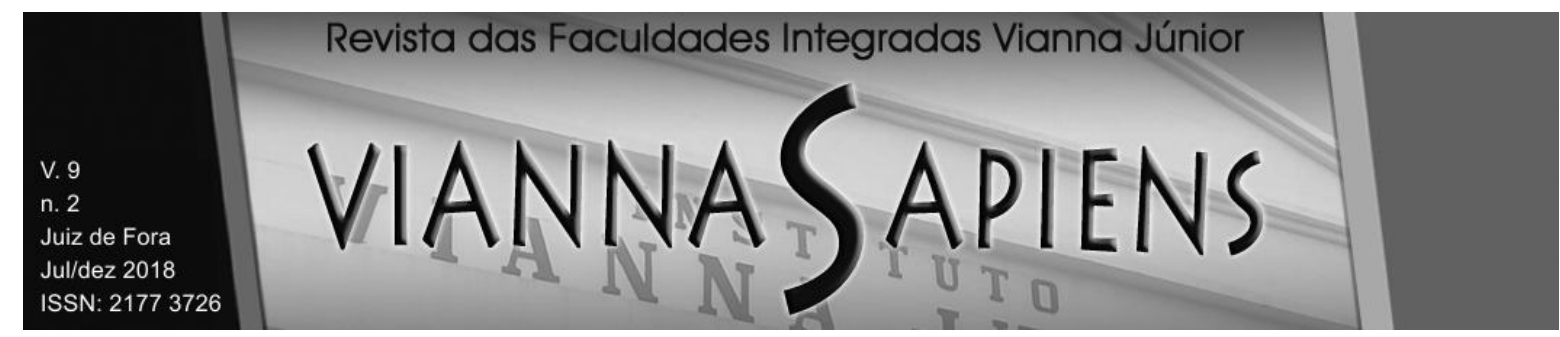

\section{SOCIEDADE CONSUMISTA, O MERCADO CONSUMIDOR E O PAPEL DO CRÉDITO NO BRASIL}

A década de 90 representou um importante marco para a economia brasileira. A estabilidade macroeconômica, que começou a ser concretizada exatamente a partir dessa década, resultou em grandes e importantes transformações em nossa economia. Medidas como o Plano Real, o regime de metas para a inflação, o câmbio flutuante, a lei de responsabilidade fiscal, entre outras, foram determinantes na construção de um cenário positivo para o desenvolvimento e a expansão do crédito no Brasil. Isso porque essa estabilidade macroeconômica criou condições que favoreceram ao aumento do investimento e do consumo das famílias, sendo parte desse consumo das famílias eventualmente financiada por crédito (PORTO et al, 2.016, p. 69).

Em nossa sociedade de consumo em massa, o crédito possui destacado papel, servindo tanto para o consumidor adquirir bens de alto valor financeiro, caracterizados como luxuosos (como carros, mansões, etc.), assim como para os de necessidades básicas do dia-a-dia, como alimentação, moradia e saúde, desempenhando relevante função social no desenvolvimento econômico de todos e da nação. Complementando esse entendimento, Erica Diniz Oliveira (apud PORTO et al, 2.016, p. 70) afirma que:

\footnotetext{
Vale enfatizar que o crédito é um elemento bastante relevante no funcionamento de uma economia. Em termos econômicos é dito que ele completa mercados; em termos menos técnicos, o que identificamos é que, na perspectiva de um consumidor (ou de uma família), o crédito permite antecipar consumo ou eventualmente até mesmo financiar determinadas escolhas, como a realização de um curso superior. No entanto, se usado indiscriminadamente, pode trazer problemas, como o superendividamento de uma pessoa física.
}

Devemos lembrar, ainda, que, atualmente, pelo trabalho do marketing ${ }^{i}$, as pessoas são estimuladas e impulsionadas ao consumo, desde cedo, de produtos e serviços, muitas vezes desnecessários à sobrevivência, no sentido de saciar um 




prazer momentâneo ou para ascensão social com a aquisição de determinada marca, por exemplo, utilizando-se, excessivamente, de recursos de instituições financeiras para esse objetivo, o que, conforme pesquisa divulgada por Timm (2006), somente nos Estados Unidos, o endividamento social, durante o período de 1.977 a 1.997, cresceu 700\%. Devemos lembrar, ainda, que a crença social, fortificada pela família, assim como a escola, de que as pessoas de sucesso são aquelas que ostentam bens de consumo valiosos, identificando o êxito, em nossa sociedade, com a posse material, instiga todos, com esse pensamento, a consumir, independente da sua capacidade financeira atual e/ou futura.

O sistema capitalista vem, portanto, se sustentando a partir da circularidade promovida pelo consumo (obtida pela chamada "democratização do crédito"), já que, quanto mais esta acontecer, mais se gerará o lucro esperado pelos agentes econômicos, criando-se mais postos de trabalho, aumentando-se, por consequência, o poder econômico da população e a aquisição de bens, sejam essenciais ou supérfluos, além de se valer do discurso "evolucionista", que prega a vida intensa (não comprometida), antecipando o futuro, sendo, conforme palavras de Daniel Bucar (2017, p. 45), maximizado tal pensamento na simbólica frase "compre agora e pague depois". Porém, com essa atitude, acarreta o comprometimento do futuro tanto do indivíduo, como o de sua família, assim como gera graves problemas ao meio ambiente e o agravamento das desigualdades sociais.

No Brasil, por muito tempo, se vivenciou um momento de euforia e crescimento econômico, com um aumento do poder aquisitivo do brasileiro, impulsionado pela sua inclusão bancária, facilitada concessão de crédito (que se materializa, por exemplo, diretamente, por meio de cartão de crédito, cheque prédatado, financiamento imobiliário e, indiretamente, por alienações fiduciárias, compra e venda com reserva de domínio, leasing, etc.), cujos dados trazidos por Daniel Bucar (2.017, p. 168), traduzem tal assertiva, pois expõe que, de dezembro de 2.007 a dezembro de 2.014, o crédito concedido a pessoa física aumentou de $15,9 \%$ para $25,6 \%$, sendo utilizado o mesmo para aquisição desde itens básicos de alimentação e higiene, até itens outrora inimagináveis de compras para 


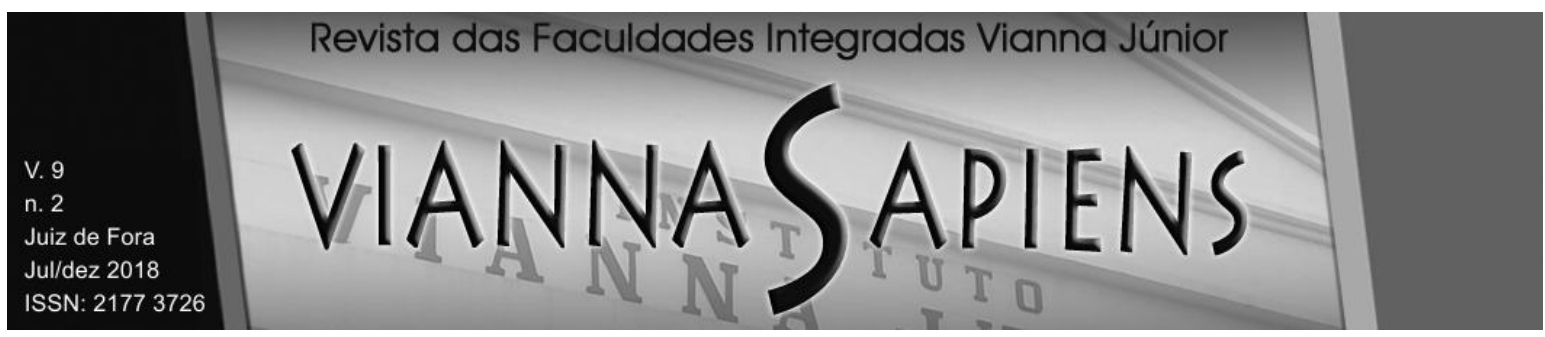

determinadas camadas da população, como carros, produtos eletrônicos (celulares, tablets e computadores), aumentando o padrão de conforto dos lares, o que, para Bertoncello (2015, p. 129) "[...] implicou a recomposição do orçamento familiar na classe trabalhadora, notadamente diante da majoração do consumo de bens duráveis de 'maior valor unitário' (automóvel e moradia)".

Deve-se consignar, por fim, que esse aumento na concessão do crédito, ocorrido após a estabilidade monetária no país, na década de 1.990, é fruto de política pública estatal contra a desaceleração econômica brasileira e com a inclusão de camadas da população antes desassistidas economicamente, com o aumento, consequente, do Produto Interno Bruto (PIB), índice de medição da riqueza de uma nação.

Porém, diante da atual grave situação econômica que se encontra nosso país (e mundialmente) e da facilidade do crédito concedido em outros tempos, como mencionado anteriormente (com altas taxas de juros), somado ao fato de que, conforme pesquisa divulgada, em 2009, pelo Instituto Brasileiro de Geografia e Estatística (apud BERTONCELLO, 2015, p. 41), um em cada cinco brasileiros é analfabeto funcional (com menos de quatro anos de estudo), demonstrando-se, assim, a vulnerabilidade e hipossuficiência do nosso consumidor (fato esse, então, de conhecimento do Estado), o papel social do crédito não está ocorrendo, concretamente, servindo somente como instrumento de lucro das instituições financeiras e de ruína para o seu tomador, tendo reflexo em toda sociedade brasileira, notadamente, desde a classe média a divisões mais pobres da nossa população (inclusive, podendo prejudicar o consumo de bens e serviços essenciais para a sobrevivência do ser humano).

$\mathrm{E}$, em virtude desta situação preocupante (e com o aumento de ações repetitivas no Poder Judiciário, em razão da inadimplência do consumidor), por não ter previsão legal específica, ainda, em nosso ordenamento jurídico (ao contrário de outros países, como, por exemplo, França, Canadá, Estados Unidos e Alemanha), doutrinadores brasileiros vêm se debruçando para melhor compreender e, assim, propor medidas capazes de proteger, eficazmente, 0 indivíduo do 


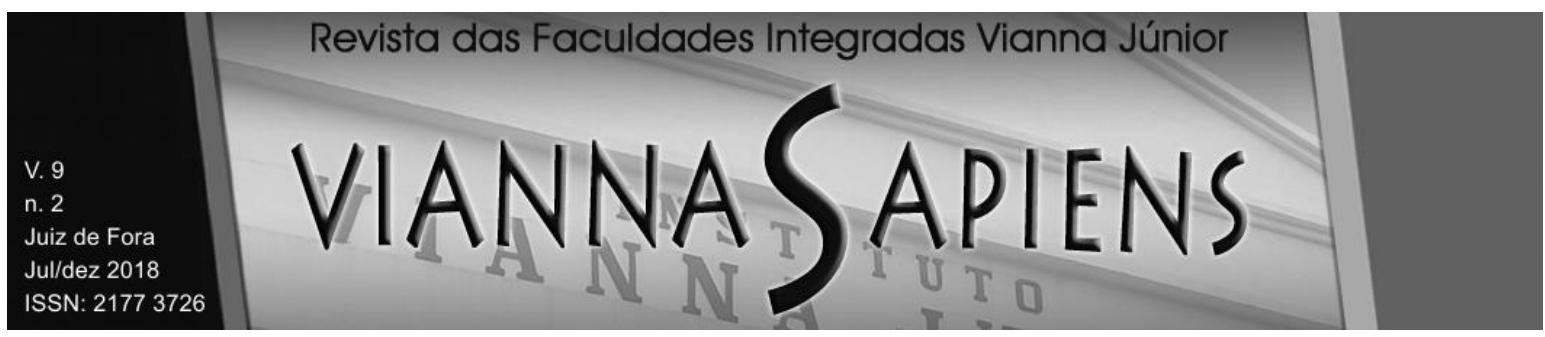

superendividamento, para se harmonizar tal celeuma com a cidadania e a dignidade da pessoa humana pregada no artigo 01ํㅡ. II e III da Constituição da República Federativa do Brasil de 1.988 ${ }^{\mathrm{ii}}$.

\section{FENÔMENO DO SUPERENDIVIDAMENTO: conceito e causa}

Podemos caracterizar o superendividamento ("sobreendividamento" em Portugal, "surendettement" na França e "over-indebtedness", no "common law") como a perda pelo consumidor da capacidade econômica de arcar com os seus compromissos assumidos, com os seus ganhos atuais e futuros provenientes do seu trabalho, com o comprometimento da sua subsistência, podendo tal situação existir, por exemplo, com apenas uma dívida. Ou seja, essa definição é mais restrita do que o próprio conceito de consumidor, presente no artigo $02^{\circ}$ da lei 8.078/1.990 ${ }^{\mathrm{iii}}$, pois, primeiramente, não se admite, naquela situação, a pessoa jurídica e, secundariamente, a despesa foi contraída para atender a uma necessidade pessoal do contratante e que passou a ou irá comprometer a aquisição de produtos e serviços básicos e necessários para a própria dignidade do tomador do crédito, como vestuário, medicamento, alimentação e moradia, com consequência negativa, portanto, na eficácia de direitos fundamentais.

E os motivos que levam as pessoas a se encontrarem em uma situação de superendividamento são os mais variados, pois o simples ato de comprar pode ser justificado para combater a ansiedade, a solidão, a raiva, a depressão, o simbolismo que representa, socialmente, determinado produto (incutido pelo próprio fornecedor do bem para atender, exclusivamente, ao seu interesse econômico), chegando a ser caracterizado, em muitos casos, como um comportamento patológico. Em suma, podemos constatar que diversos fatores podem levar 0 indivíduo ao superendividamento, desde acontecimentos inesperados a situações previsíveis levadas a cabo pelo próprio endividado. 


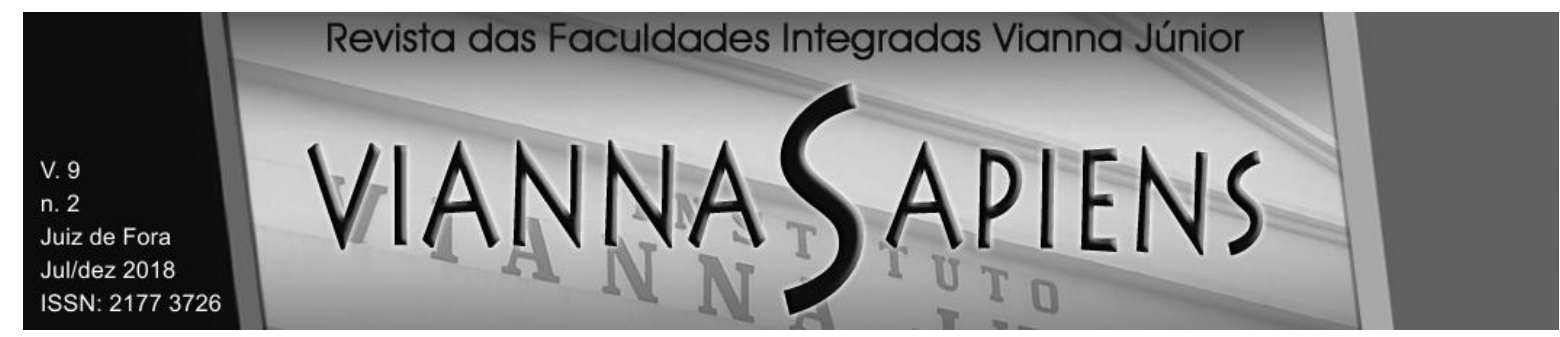

\subsection{O perfil e as espécies de superendividados}

O superendividamento é condição exclusiva da pessoa física e de boa-fé (ao contrário da jurídica que já conta com o instituto, em nosso ordenamento jurídico, da falência e dos benefícios concedidos por meio da lei nacional 11.101/2.005) que não tem condição estrutural de solver suas dívidas de consumo por conta própria (excluídas, portanto, as decorrentes de delitos, alimentos ou de tributos), mesmo com o comprometimento total de seus rendimentos e que necessita de auxílio para a sua reestruturação econômico-financeira, para que não haja risco à sua dignidade.

Com fundamento na sua origem, ainda, o superendividamento é classificado, pela doutrina, como ativo ou passivo, de acordo com o comportamento do próprio tomador do crédito: na primeira hipótese, o próprio consumidor, em uma atitude temerária, utiliza-se de maneira excessiva de recursos financeiros, por meio de empréstimos, comprometendo, assim, o seu próprio orçamento, muitas vezes, levado por uma atitude inconsciente e manipulada por estratégias abusivas de marketing dos fornecedores de produtos e serviços, que criam a necessidade no receptor daquela mensagem (fato esse corroborado pela exposição excessiva do brasileiro à televisão), assim como diante da facilidade do crédito, acumulando dívida bastante superior à sua renda e patrimônio; por outro lado, a segunda hipótese (superendividamento passivo) ocorre por infortúnio do devedor que, por uma situação a que não deu causa (não agiu de má-fé ou por má-gestão), diretamente, passa a possuir uma condição que não lhe assegura o pagamento de suas dívidas atuais e futuras (como, por exemplo, desemprego, divórcio ou redução salarial), comprometendo o seu mínimo vital.

Não tendo condições, assim, de arcar com as dívidas assumidas sem comprometer o necessário para a sua sobrevivência, deverá o consumidor receber a tutela legal do nosso ordenamento jurídico, na hipótese do consumo excessivo, já que, em muitos casos, foi o mesmo exposto a atitudes/práticas ilegais e agressivas pelo fornecedor do crédito e ao risco pela sua concessão indiscriminada e irresponsável, gerando, assim, a situação econômica frágil em que se encontra. 


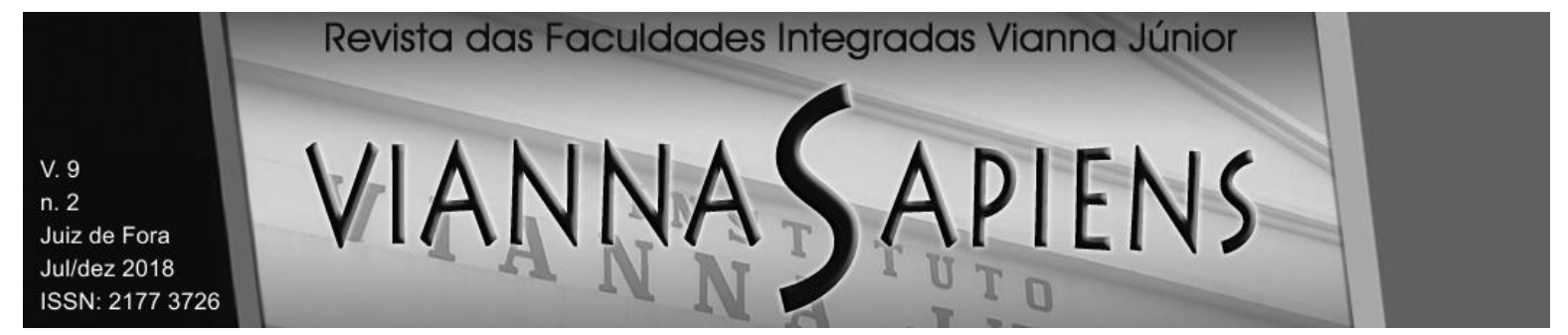

Portanto, da caracterização do superendividamento é que nós iremos evitar o prejuízo total para o indivíduo, com a sua devida readequação, tanto no aspecto econômico, como emocional e social, na busca de seu mínimo existencial, assim como preservar o próprio mercado de consumo, com a reintegração de um de seus agentes, desta vez, apto ao consumo consciente e sadio.

\subsection{Os efeitos do superendividamento}

O superendividamento trará consequências não só no aspecto financeiro do indivíduo, como, por exemplo, com a sua exclusão do mercado de consumo, mas também repercussão pessoal, já que, de acordo com o que apontam estudos citados por Eduardo Antônio Andrade Amorim (2010), o consumidor, diante de sua nova realidade econômica, terá que reformular todas as suas relações com as pessoas de seu antes círculo social, podendo, inclusive, ser isolado do seu convívio (por deliberação própria ou não), trazendo abalo, com isso, a sua autoestima e à própria vida do indivíduo (com términos de relacionamentos conjugais e suicídios ou se submetendo a constrangedores processos judiciais com a penhora do seu patrimônio para a satisfação de seus credores), cerceando-o de viver com dignidade, conforme preceitua o artigo 1ำ III da Constituição da República Federativa do Brasil de 1.988, sendo o gerenciamento deste risco, pelo Estado, necessário para preservar o mínimo existencial do endividado.

Além disso, devemos apontar também que o sobreendividamento trará repercussão ao mercado de consumo (risco sistêmico), pois sem a participação do consumidor (peça-chave do sistema), poderá ser comprometido todo ciclo, com a diminuição ou extinção do seu desenvolvimento, acarretando desempregos, aumento de preços de produtos e serviços, decorrente da sua escassez e pelo crescimento da demanda, dentre outras repercussões sociais e mundiais, diante de uma visão fragmentada sua como sujeito econômico. 


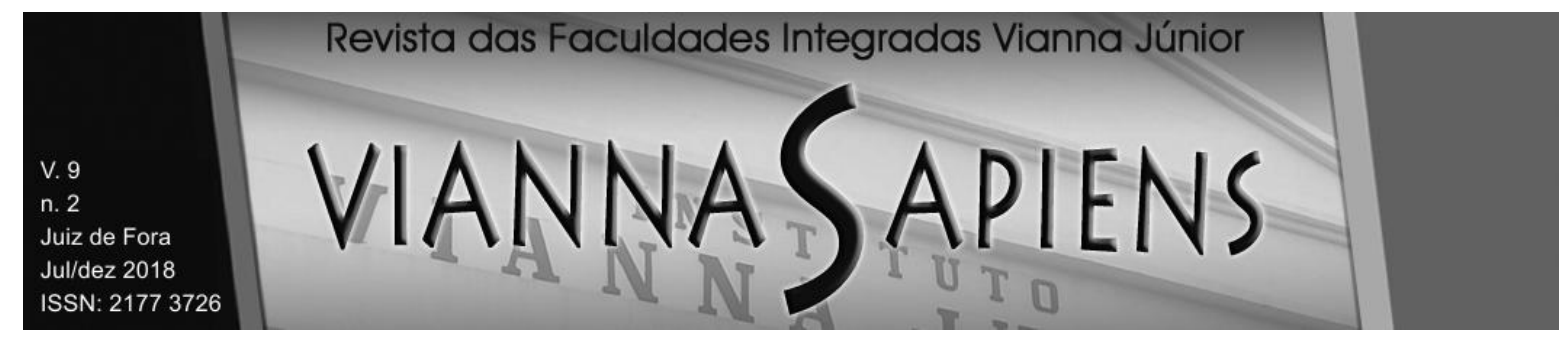

\subsection{A previsão legal da proteção do superendividado no Direito brasileiro}

O percurso histórico evidencia que apenas o patrimônio da pessoa responde ao inadimplemento de obrigações civis. Essa premissa encontra-se, na atualidade, não apenas inserida no catálogo de direitos fundamentais da Constituição da República (art. 05ํㅡㄴ LXVII), mas figura em cartas internacionais de Direitos Humanos, de que é exemplo o art. $7^{\circ}$, VII da Convenção Americana de Direitos do Homem, subscrita pela República brasileira. Afora o teste de solvabilidade previsto para coagir o pagamento de débitos alimentícios, não mais há qualquer respaldo ao pagamento de obrigações inadimplidas por meio do corpo do devedor. Trata-se, portanto, de paradigma civilizatório fundamental à contemporaneidade (BUCAR, 2017, p. 201).

Do ponto de vista legislativo, há necessidade de uma norma legal específica acerca do tema, devendo ser utilizada como referência a de países como França, Canadá e Alemanha, conforme sugestiona a professora Cláudia Lima Marques, citada por Amorim (2010), com a adoção de diversos instrumentos já implementados, com sucesso, nesses países, como, por exemplo, o procedimento de falência individual do superendividado presente no direito francês, tendo em vista as diversas modalidades de condutas que desviam da função social dos contratos, levando o consumidor ao superendividamento, originado, na maioria dos casos, por uma má-fé do prestador/fornecedor do produto ou serviço (devemos mencionar, ainda, que já existe em tramitação no Poder Legislativo nacional, Projeto de Lei do Senado Federal número 283/2.012, que visa concretizar essa proteção ao mínimo existencial do superendividado, modificando diversos artigos do Código de Defesa do Consumidor).

Porém, mesmo com a ausência desta previsão legal direta, temos mecanismos adequados para proteger o superendividado (indiretamente), em virtude do disposto na Constituição da República Federativa do Brasil de 1.988 e no próprio Código de Defesa do Consumidor, por meio de normas gerais que garantem essa tutela. 


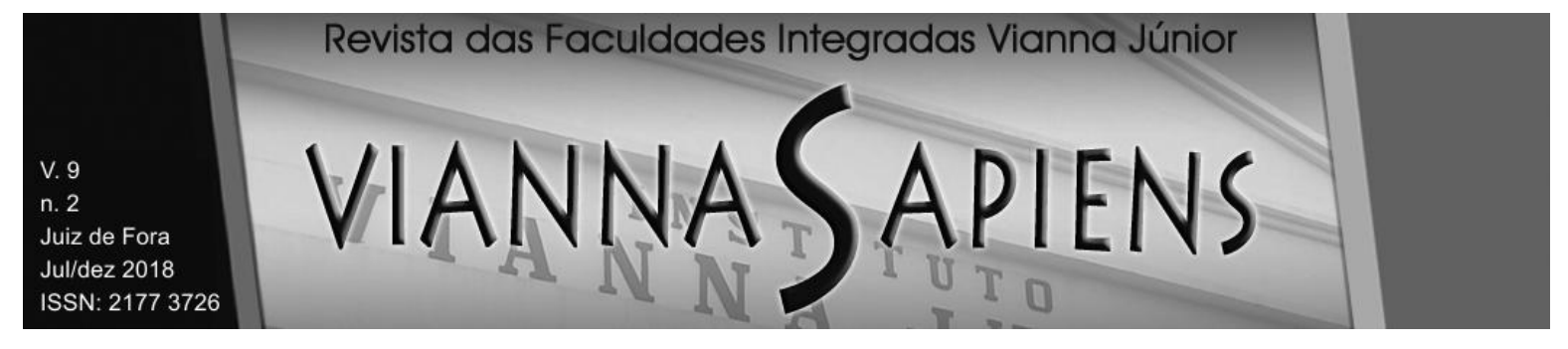

Em primeiro lugar, nossa Lei Maior de 1988 erigiu a dignidade da pessoa humana como valor superior de nosso ordenamento jurídico, o que proíbe, por exemplo, infligir o próprio corpo do indivíduo para pagamento de uma obrigação civil (com a exceção da dívida alimentar), já que lesaria também convenções internacionais de direitos humanos que o Brasil seja signatário ${ }^{i v}$, além de prever como direito fundamental de todos a defesa do consumidor, parâmetros esses essenciais para a análise, interpretação e aplicação a situações que tenham como parte este vulnerável e que se encontra em uma posição incompatível com a sua própria condignidade.

Em segundo lugar, a defesa do consumidor é prevista como um direito fundamental de todos, o que gera, por consequência, o dever do Estado na sua consecução, além de ser um dos princípios da ordem econômica brasileira, presente no artigo 170, V da Constituição da República Federativa do Brasil de $1.988^{\mathrm{V}}$ e que, de acordo com a Política Nacional de Consumo, prevista no artigo $04^{\circ}$ da lei nacional 8.078/1.990, o legislador deverá sempre atender às necessidades dos consumidores, com respeito à sua dignidade, saúde, segurança e seus interesses econômicos, objetivando a melhoria da qualidade de vida de todos e a transparência e harmonia das relações consumidoras (lembrando-se sempre que a vulnerabilidade do consumidor é presunção absoluta prevista no artigo 04ํㅡ. I do Código de Defesa do Consumidor ${ }^{\text {vi }}$.

Ainda, no próprio Código de Defesa do Consumidor, temos, de maneira generalista (uma das principais características dos sistemas protetivos dos vulneráveis, conforme ensina Vitor Guglinski (2012) , é de se encontrarem baseados em cláusulas abertas), comandos legais que visam proteger todos aqueles que se encontram em uma situação de vulnerabilidade consumerista, podendo se enquadrar, nesta hipótese, o superendividado, como, por exemplo, em seu artigo 06º, IV, quando determina como direito básico do consumidor a proteção contra a publicidade enganosa e abusiva, métodos comerciais coercitivos ou desleais, bem como contra práticas e cláusulas abusivas ou impostas no fornecimento de produtos e serviços, que, em sua maioria, incorrem as instituições financeiras, utilizando-se 


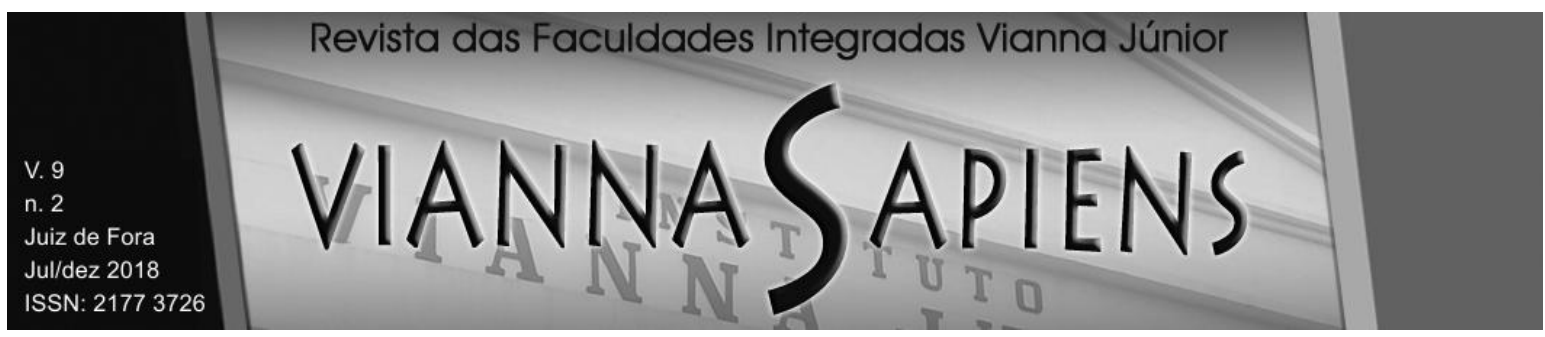

de subterfúgios para se conceder, coercitiva e indiscriminadamente, crédito a todos, sem atentar para a capacidade econômica do tomador, podendo todo aquele prejudicado (e de boa-fé) com tal conduta lesiva requerer a modificação das cláusulas contratuais que estabeleçam prestações desproporcionais ou a sua revisão em razão de fatos supervenientes que as tornem excessivamente onerosas,

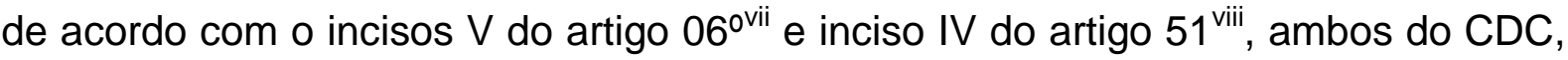
estabelecendo-se verdadeira justiça social com o reequilíbrio contratual.

E, ainda, no artigo $52^{\mathrm{ix}}$ do Código de Defesa do Consumidor, visualizamos previsão legal específica acerca da concessão de financiamento, quando impõe ao concedente a obrigação de informar, prévia e adequadamente, ao beneficiário daquela prestação, sobre o preço do produto ou serviço em moeda corrente nacional; montante dos juros de mora e da taxa efetiva anual de juros; acréscimos legalmente previstos; número e periodicidade das prestações; e soma total a pagar, com ou sem o financiamento.

Com relação, ainda, à proteção do superendividado, utilizando como fundamento legal o Código de Defesa do Consumidor, nós temos, também, nesta lei, a obrigatoriedade da transparência das regras nas relações entre o vulnerável e o fornecedor do produto/serviço, com a prestação de esclarecimentos e informações necessárias (claras e precisas) antes da contratação, com a divulgação do verdadeiro valor do crédito concedido (com a exposição de todos os encargos e taxas embutidas), dando, ainda, a oportunidade do consumidor de refletir efetivamente acerca daquilo que está contratando (respeitando tanto a sua renda/patrimônio atual como futuro), livre de qualquer exposição publicitária exagerada e acreditar naquilo que o prestador oferta (ficando o mesmo vinculado juridicamente à sua proposta, não podendo alterá-la unilateralmente, conforme preceitua o artigo 30 da lei nacional 8.078/1.990).

Além disso, evitando-se estigmatizar eternamente o indivíduo por sua delicada situação financeira, a própria lei nacional 8.078/1.990 determina o prazo máximo de 05 (cinco) anos para que o nome e o CPF do devedor se mantenha nos bancos de dados para concessão de crédito (com previsão também no Projeto de 


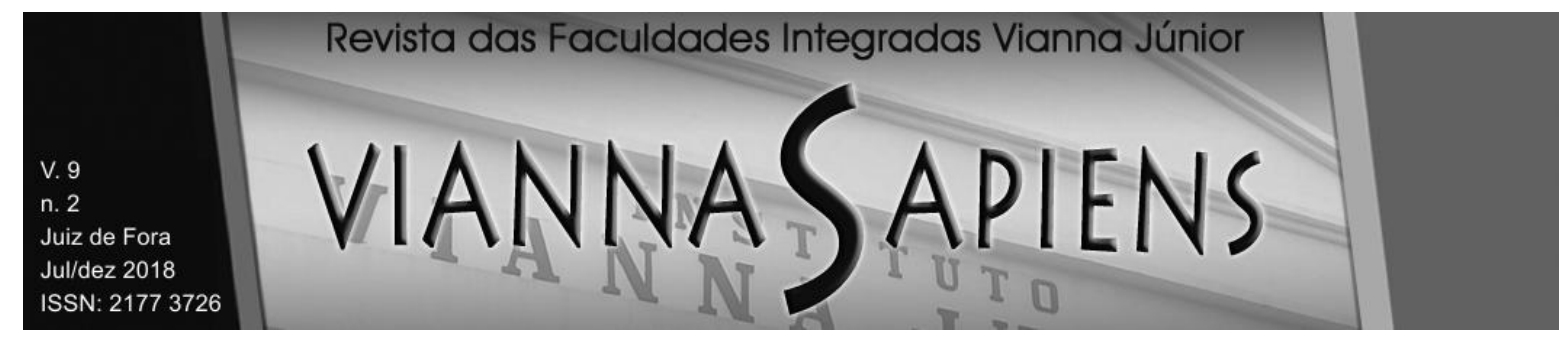

Lei do Senado 283/2012 da obrigatoriedade de se constar cláusula, no contrato de financiamento, com a data em que serão retirados os dados do consumidor deste cadastro restritivo do crédito).

E a intenção do legislador ao caracterizar o consumidor como vulnerável foi de equilibrar a (sempre desequilibrada) relação entre este e o fornecedor (valendose, pois, do princípio constitucional da isonomia), por meio de instrumentos legais previstos na lei 8.078/1.990, para a facilitação da defesa da parte mais fraca (como, por exemplo, com a previsão da responsabilidade objetiva do fornecedor e das ações coletivas), além de se garantir um mínimo material para implementar um projeto de vida possível, como seu direito fundamental e que é previsto na Lei Maior de 1.988 (o que para isso, também, por exemplo, se previu - não somente ao consumidor superendividado, mas a todos os indivíduos - o regime de impenhorabilidade de bens em nosso ordenamento, dentre os quais, o "bem de família", previsto na lei nacional 8.009/90 e nas disposições legais do Código de Processo Civil ${ }^{\times i}$.

Devemos lembrar, ainda, que o extinto Código de Processo Civil de 1973 tinha, em seu artigo $778^{\text {xii }}$, a previsão da extinção total de todas as obrigações não cumpridas pelo devedor insolvente, após a liquidação do seu patrimônio, devendo ser considerado como um norte para as futuras previsões legais de tratamento do superendividamento, como leciona Daniel Bucar (2017, p. 172), ao afirmar que:

[...] qualquer tratamento do superendividado não deve ignorar a extinção prevista no art. 778 do Código de Processo Civil, tal como o faz o Projeto de Lei de Superendividamento. A discharge brasileira deve ser considerada um ponto de partida para qualquer debate para solucionar o tema do patrimônio superendividado. Trata-se de conquista evolutiva e civilizatória em direção ao remédio desejado, e ignorá-la representa violação ao princípio da proibição do retrocesso social.

Além disso, doutrinadores nacionais defendem que o sistema recuperacional presente na lei nacional 11.101/2005 (para a proteção da atividade empresarial), poderá ser utilizada pelo consumidor superendividado, já que a proteção final que se 


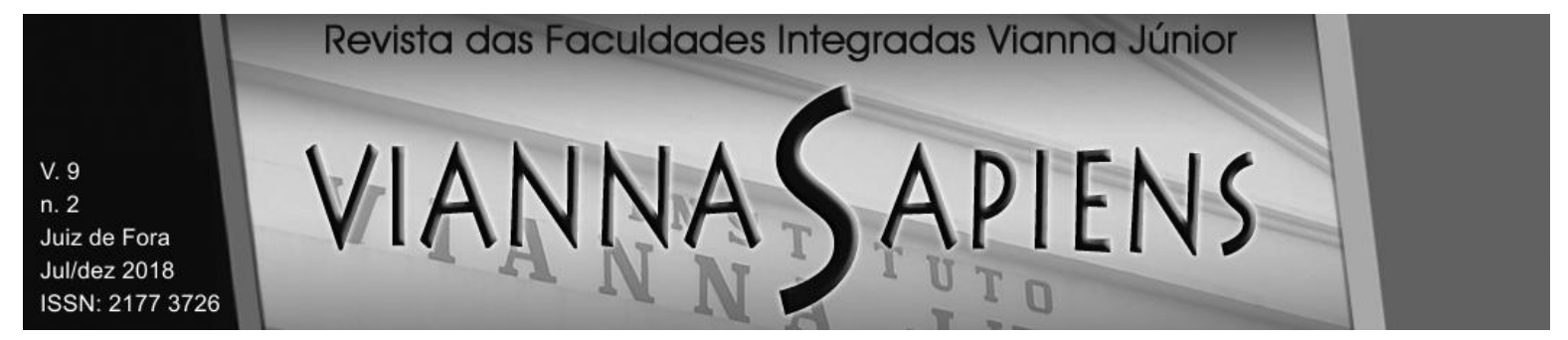

deseja, em ambos os casos, é uma só: preservação do ser humano com dignidade. E a defesa se baseia legalmente no artigo 52 do Código Civil ${ }^{\text {xiii }}$, que preceitua que a proteção que se dá aos direitos de personalidade se estenderá à jurídica, o que, por analogia e de maneira invertida, se prega que tudo legalmente for utilizado em prol desta ficção jurídica se ampliará ao indivíduo, daí a possibilidade de utilização dos mecanismos presentes na Lei de Falência e Recuperação Judicial, tais como a moratória, suspensão de todas as ações liquidadas e execuções contra o devedor e o plano especial de pagamento dos débitos quirografários para auxiliar a pessoa física endividada.

Portanto, mesmo que não haja, ainda, previsão legal específica que trate do fenômeno do superendividamento, em nosso ordenamento jurídico brasileiro, ao se analisar e interpretar este, de forma unitária e harmônica, verificamos a existência de instrumentos que podem ser utilizados para salvaguardar a dignidade de todos aqueles que se encontrem nesta delicada situação financeira, concretizando-se, assim, um direito social, com previsão tanto constitucional como infraconstitucional, qual seja, a defesa do consumidor superendividado, por meio de uma recuperação do seu estado econômico-patrimonial, dando-lhe condições mínimas para concretizar seu projeto de vida.

\section{CONSIDERAÇÕES FINAIS}

Assim, podemos concluir que o crédito, atualmente, em nossa sociedade de consumo em massa, possui importante papel, diante da diversidade de sua utilização, já que pode ser usado tanto para a aquisição de produtos básicos e necessários do dia-a-dia, como alimentação, vestuário e medicamento, como para compra de itens sofisticados, como eletrônicos, veículos e imóveis de luxo, e que, inclusive, se houver a sua falta, em muitos casos, poderá comprometer o indivíduo em cumprir com as suas obrigações diárias. O crédito, portanto, assumiu um 


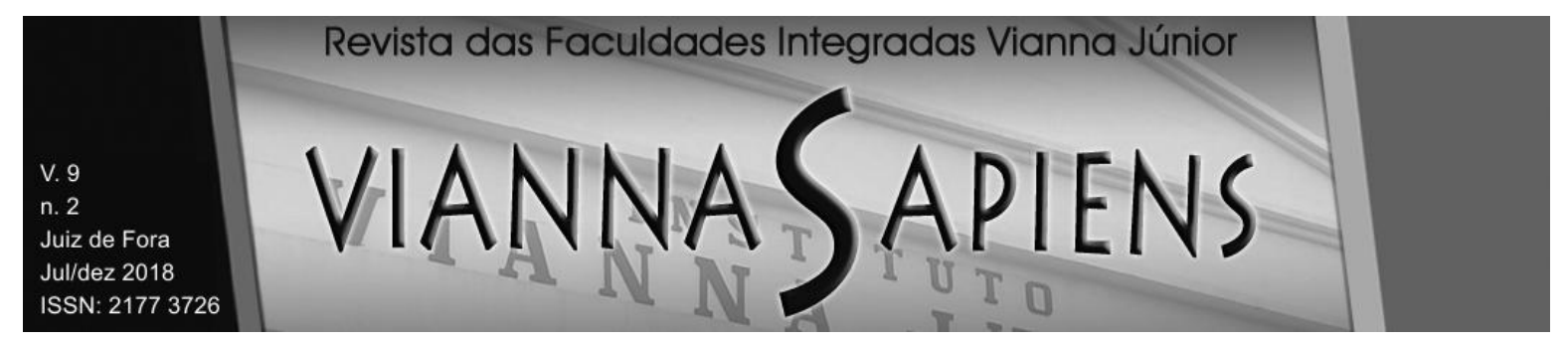

destaque duplo, pois passa a ser objeto principal de relação consumerista, assim como auxiliar no consumo de bens e serviços.

Além disso, nos últimos tempos, no Brasil, a multiplicação das fontes de crédito (chamada, pela doutrina, de "democratização" ou "vulgarização") tem sido utilizada como política estatal para o aumento e nova configuração da "classe média", com a inclusão, mobilidade e desenvolvimento social, por meio do incremento da renda das famílias brasileiras.

Vivemos em uma cultura que exige 0 endividamento do cidadão para que possa usufruir de todos os benefícios que a modernidade oferece, além de ser baseada no valor do "ter" e não do "ser", onde produtos são símbolos de "status", e que é incentivada (inclusive pelo Estado) pela concessão irresponsável do crédito pelas instituições financeiras, assim como pela publicidade agressiva utilizada pelos prestadores/fornecedores de serviços e produtos que estimulam ou compelem o consumo, em uma economia "do logo, do excesso e do lixo", cujo discurso capitalista prega a vida intensa (com um futuro não comprometido), retirando-se, desta forma, a racionalidade do consumidor neste ato.

Preocupação essa ainda maior na realidade brasileira, pois 0 comprometimento da renda familiar dos estratos sociais brasileiros de baixa renda não está atrelado às despesas necessárias, mas sim com a elevação do padrão de vida, sem o acompanhamento de receita necessária, além da baixa escolaridade da população, que se ressente de uma educação financeira, levando-se, assim, a um estado crítico patrimonial.

A concessão desmedida do crédito, nos tempos atuais, com a inclusão de inúmeras pessoas no sistema bancário, tem gerado a insolvência de muitas famílias (originada por um consumo impulsivo ou mesmo desorganização financeira, por exemplo), verificada em todas as classes sociais, acarretando diversas consequências, tanto para o indivíduo, assim como para a sociedade (com a redução do ritmo da economia, pela queda no consumo, por exemplo).

Surge, nesse cenário, o superendividamento, fenômeno esse global, e que vem chamando a atenção de todos os países, pois não se trata somente de um 


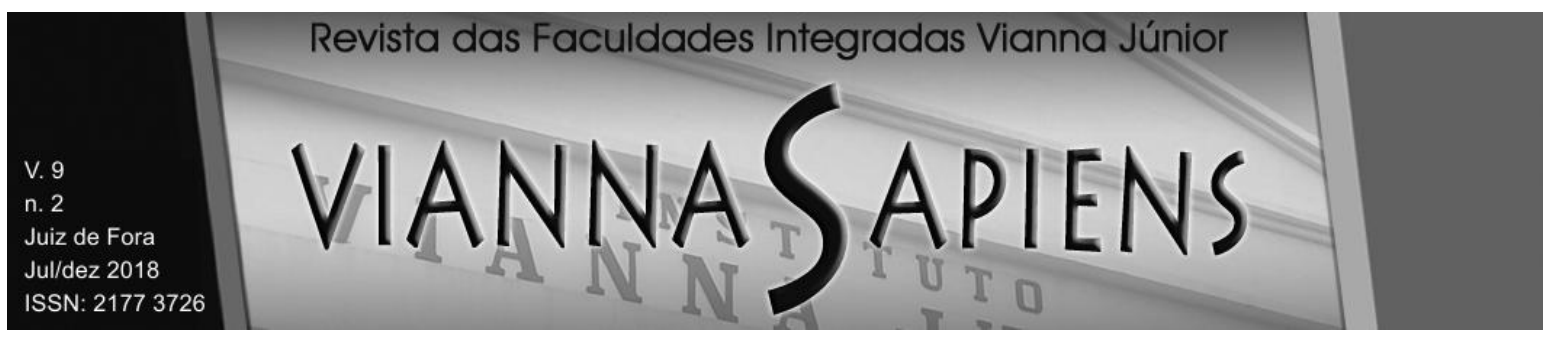

momento temporário de inadimplência do consumidor, mas sim uma impossibilidade da própria pessoa física de suprir suas necessidades básicas, com alimentação, vestuário, medicamento e moradia e incapacidade de gerir os seus próprios bens e que, se não for tratada, ameaça a sua própria dignidade como ser humano.

Como visto, o superendividamento é a impossibilidade não momentânea do consumidor, pessoa física e de boa-fé, de cumprir com o conjunto de suas dívidas atuais e futuras de consumo e que pode ter diversas motivações, constituindo um dos principais problemas contemporâneos, em virtude da extrema facilidade de acesso ao crédito, além do próprio estímulo do mercado, sendo que a batalha, em caráter global, ganhou aura de combate à própria exclusão social do indivíduo.

Estando nesta delicada situação financeira, mesmo que não haja previsão legal específica no ordenamento jurídico brasileiro (estando em trâmite o Projeto de Lei do Senado número 283/2.012, com esse objetivo), em virtude do direito social (e individual) à reabilitação patrimonial, em nosso entendimento, o consumidor superendividado (ativo inconsciente e o passivo) poderá pleitear a tutela do Estado (tendo em vista a colaboração deste na política de consumo desenfreado de sua população, distribuindo-se os efeitos e riscos desse fenômeno na teia social), já que, em muitos casos, foi vítima de práticas comerciais agressivas, por meio da publicidade, assim como a concessão irresponsável do fornecedor de crédito, sendo essa caracterização o passo inicial para a prevenção da ruína total deste vulnerável, sob o aspecto econômico, moral e social, com a sua reinclusão, de maneira sadia, no mercado e na sociedade, assim como acautelar o futuro da sociedade de risco, tanto nacional como mundial, com fundamento constitucional no dever de cooperação e solidariedade.

E essa proteção que irá se pleitear tem como fundamento, primeiramente, constitucional, por meio do princípio da defesa do consumidor (artigos 05으, XXXII e $170, V$ ) e o da dignidade da pessoa humana (artigo 01으. III), devendo o Estado assegurar, àquele vulnerável, condições mínimas de sobrevivência digna e, secundariamente, consumerista (já que os contratos de fornecimento de crédito se enquadram como relação de consumo), com base no Código de Defesa do 


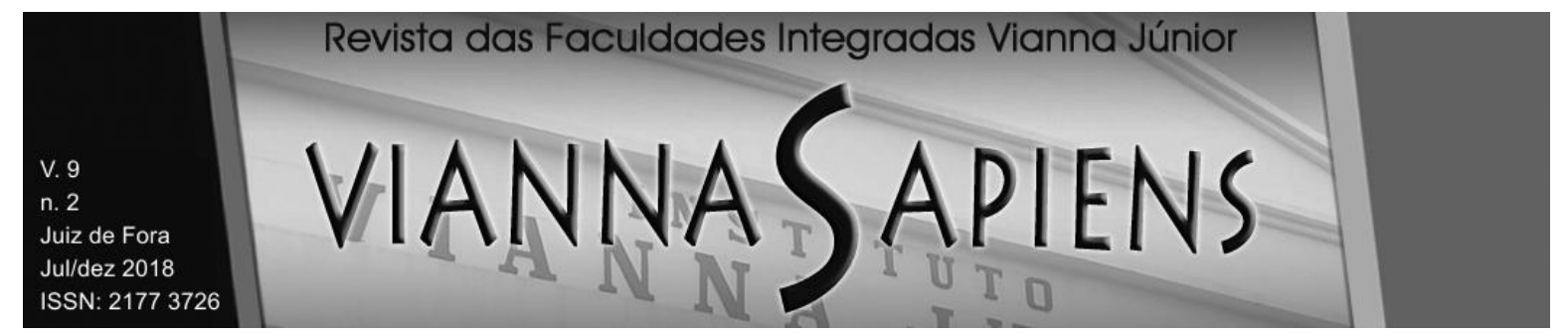

Consumidor, com o intuito de privilegiar o consumidor de boa-fé como ser humano que é, em detrimento do crédito, dando-lhe condições de solver as suas dívidas, sem onerá-lo nas suas condições mínimas de vivência.

Além disso, com fundamento no artigo 52 do Código Civil (analisado de maneira invertida), defende-se, em solo brasileiro, a utilização do sistema recuperacional de pessoas jurídicas, previsto na lei número 11.101/2.005, com os seus diversos instrumentos legais, para preservação constitucional (artigo 01ํ. III) da dignidade, também, da pessoa humana que se encontra nesta delicada situação.

Portanto, tendo em vista que não se pode valorizar o crédito em detrimento do ser humano, se faz necessária a previsão urgente de uma lei específica que venha a possibilitar, real e efetivamente, ao consumidor superendividado de boa-fé de solver o seu débito, e que, sozinho, não encontra meios para tanto, com a manutenção e proteção de uma vida digna sua e de sua família, através de meios materiais mínimos que garantam a sua promoção, conforme previsão constitucional, com a desejada pacificação social e redução da desigualdade existente na sociedade brasileira, sob o risco da sua exclusão social e, novamente, do mercado que ingressara mediante o aumento do poder aquisitivo, via o acesso ao crédito.

\section{REFERÊNCIAS}

AMORIM, Eduardo Antônio Andrade. $O$ superendividamento do consumidor. Revista Jus Navigandi, Teresina, ano 15, n. 2658, 11 out. 2010. Disponível em: <https://jus.com.br/artigos/17597>. Acesso em: 23 abr. 2018

BERTONCELLO, Káren Rick Danilevicz. Superendividamento do consumidor: mínimo existencial - casos concretos. São Paulo: Editora Revista dos Tribunais, 2.015 .

BRASIL. Constituição da República Federativa do Brasil de 1.988. Disponível em: <http://www.planalto.gov.br/ccivil_03/constituicao/constituicao.htm>. Acesso em: 19 jun. 2016. 


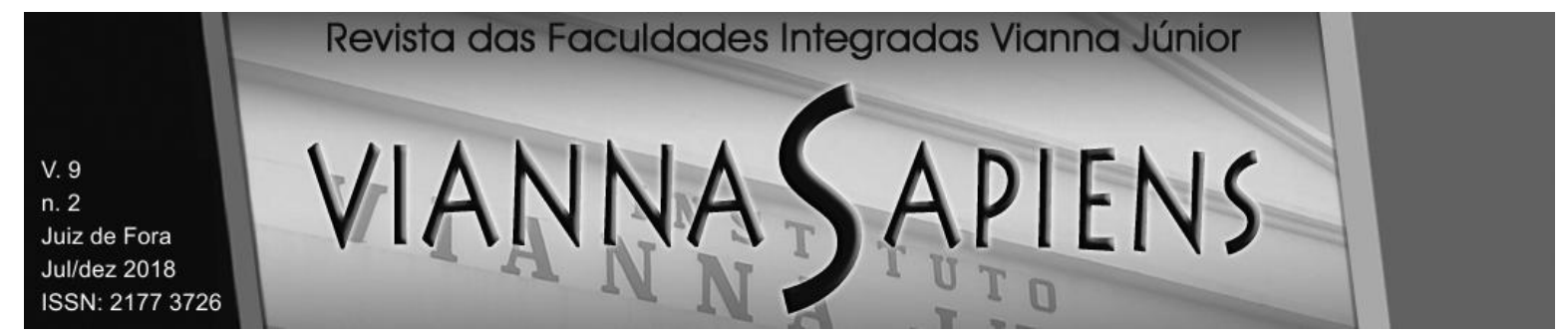

Lei número 5.869, de 11 de janeiro de 1.973. Institui o Código de Processo Civil. Disponível em:

<http://www.planalto.gov.br/ccivil_03/LEIS/L5869impressao.htm>. Acesso em: 29 set. 2.018 .

Lei 8.078, de 11 de setembro de 1.990. Dispõe sobre a proteção do consumidor e dá outras providências. Disponível em:

<http://www.planalto.gov.br/ccivil_03/leis/L8078.htm>. Acesso em: 19 jun. 2.016.

Lei 8.009, de 29 de março de 1.990. Dispõe sobre a impenhorabilidade do bem de família. Disponível em:

<http://www.planalto.gov.br/ccivil_03/leis/L8009.htm>. Acesso em: 19 jun. 2.016.

Lei 10.406, de 10 de janeiro de 2.002.Institui o Código Civil. Disponível em: <http://www.planalto.gov.br/CCivil_03/leis/2002/L10406.htm>. Acesso em: 01 fev. 2.018.

Lei 11.101, de 09 de fevereiro de 2.005. Regula a recuperação judicial, a extrajudicial e a falência do empresário e da sociedade empresária. Disponível em: <http://www.planalto.gov.br/ccivil_03/_ato2004-2006/2005/lei/l11101.htm>. Acesso em 19 jun. 2.016.

Projeto de lei $n^{\circ}$ 283/2012. Altera a lei $n^{\circ} 8.078$ de 11 de setembro de 1990 (Código de Defesa do Consumidor) para aperfeiçoar a disciplina do crédito do consumidor e dispor sobre a prevenção do endividamento. Disponível em: $<$ https://www.senado.leg.br/atividade/rotinas/materia/getPDF.asp?t=112479\&tp=1>. Acesso: 06 jan. 2.017.

Lei número 13.105, de 16 de março de 2.015. Institui o Código de Processo Civil. Disponível em:<http://www.planalto.gov.br/ccivil_03/_Ato20152018/2015/Lei/L13105.htm>. Acesso: 29 set. 2.018.

BUCAR, Daniel. Superendividamento: reabilitação patrimonial da pessoa humana. São Paulo: Saraiva, 2.017.

GUGLINSKI, Vitor. Consumidores hipervulneráveis. Revista Jus Navigandi. Disponível em: <https://jus.com.br/artigos/22757>. Acesso em: 23 abr. 2016. 


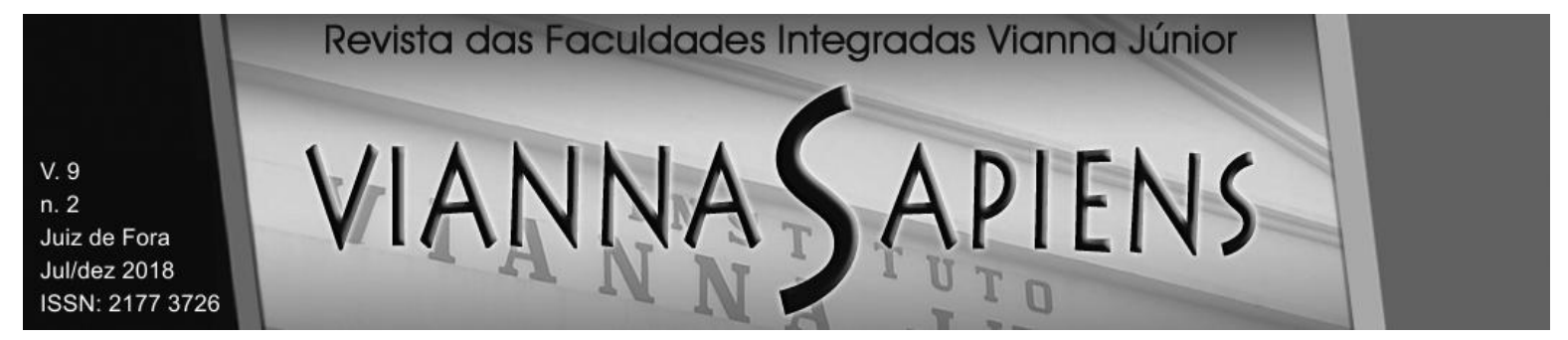

PORTO, José Maristrello et al. Superendividamento no Brasil. II v. Curitiba: Juruá, 2.016 .

\author{
TIMM, Luciano Benetti. O superendividamento e o direito do consumidor. Âmbito \\ Jurídico. Disponível em: <http://www.ambito- \\ juridico.com.br/site/index.php?n_link=revista_artigos_leitura\&artigo_id=1330>. \\ Acesso em 15 mai. 2016.
}

\begin{abstract}
' Com os atuais meios de comunicação, a transmissão da cultura, antes limitada pelo contato direto com os pais, professores ou pessoas próximas que a detinham, hoje se faz de maneira global, o mesmo ocorrendo com a produção e o consumo em grande escala, originando-se aí o termo "sociedade de consumo em massa". Porém, essa divulgação cultural não se dá, em tese, para o desenvolvimento humano, mas sim para atender aos interesses comerciais dos produtores e fornecedores de seus serviços e produtos, que incutem, em seus comerciais, por meio de técnicas de receptividade passiva, um prazer, ao pretenso consumidor, superficial e temporário (por meio de fantasias e escapismos), diante da necessidade constante de consumo e venda. Celebra, portanto, nossa atual coletividade, o consumismo, banalismo e o comercialismo, por meio de cultura apassivadora que não dá a oportunidade aos seus indivíduos de pensarem sobre o seu próprio comportamento.

ii Artigo $01^{\circ}$ da Constituição da República Federativa do Brasil de 1.988: "A República Federativa do Brasil, formada pela união indissolúvel dos Estados e Municípios e do Distrito Federal, constitui-se em Estado Democrático de Direito e tem como fundamentos: (...) II - a cidadania; III - a dignidade da pessoa humana; (...)".

iii Artigo $2^{\circ}$ da lei 8.078/1.990: "Consumidor é toda pessoa física ou jurídica que adquire ou utiliza produto ou serviço como destinatário final. Parágrafo único. Equipara-se a consumidor a coletividade de pessoas, ainda que indetermináveis, que haja intervindo nas relações de consumo".

iv Nesse sentido, o consubstanciado no artigo 42 do Código de Defesa do Consumidor: "Na cobrança de débitos, o consumidor inadimplente não será exposto a ridículo, nem será submetido a qualquer tipo de constrangimento ou ameaça".

v Artigo 170 da Constituição da República Federativa do Brasil de 1.988: "A ordem econômica, fundada na valorização do trabalho humano e na livre iniciativa, tem por fim assegurar a todos existência digna, conforme os ditames da justiça social, observados os seguintes princípios: [...] V - defesa do consumidor; [...]".

vi Artigo $04^{\circ}$ da lei 8.078/1.990: "A Política Nacional das Relações de Consumo tem por objetivo o atendimento das necessidades dos consumidores, o respeito à sua dignidade, saúde e segurança, a proteção de seus interesses econômicos, a melhoria da sua qualidade de vida, bem como a transparência e harmonia das relações de consumo, atendidos os seguintes princípios: I reconhecimento da vulnerabilidade do consumidor no mercado de consumo";

vii Artigo $06^{\circ}$ da lei 8.078/1.990: "São direitos básicos do consumidor: [...] V - a modificação das cláusulas contratuais que estabeleçam prestações desproporcionais ou sua revisão em razão de fatos supervenientes que as tornem excessivamente onerosas; "

viii Artigo 51 da lei 8.078/1.990: "São nulas de pleno direito, entre outras, as cláusulas contratuais relativas ao fornecimento de produtos e serviços que: [...] IV - estabeleçam obrigações consideradas iníquas, abusivas, que coloquem o consumidor em desvantagem exagerada, ou sejam incompatíveis com a boa-fé ou a equidade; "

${ }^{\text {ix }}$ Artigo 52 da lei 8.078/1.990: "No fornecimento de produtos ou serviços que envolva outorga de crédito ou concessão de financiamento ao consumidor, o fornecedor deverá, entre outros requisitos, informá-lo prévia e adequadamente sobre: I - preço do produto ou serviço em moeda corrente nacional; II - montante dos juros de mora e da taxa efetiva anual de juros; III - acréscimos
\end{abstract}




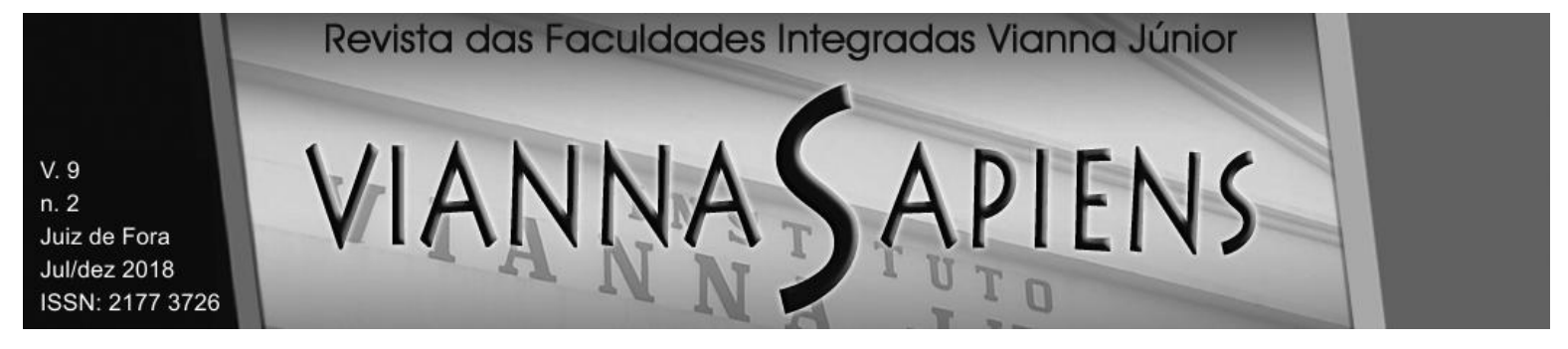

legalmente previstos; IV - número e periodicidade das prestações; $V$ - soma total a pagar, com e sem financiamento".

${ }^{x}$ Artigo 30 da lei 8.078/1.990: "Toda informação ou publicidade, suficientemente precisa, veiculada por qualquer forma ou meio de comunicação com relação a produtos e serviços oferecidos ou apresentados, obriga o fornecedor que a fizer veicular ou dela se utilizar e integra o contrato que vier a ser celebrado".

xi O direito brasileiro possui previsão, em normas esparsas, de proteção legal de bens caracterizados como indispensáveis para a manutenção do devedor e que, ao se analisar em comparação aos seus congêneres estrangeiros, é rigoroso em proteger o chamado "patrimônio de dignidade", como, por exemplo, com a impenhorabilidade do salário (Código de Processo Civil) e do bem de família e dos bens móveis que o guarnecem (lei nacional 8.009/1.990).

xii Artigo 778 do Código de Processo Civil de 1.973: "Consideram-se extintas todas as obrigações do devedor, decorrido o prazo de 05 (cinco) anos, contados da data do encerramento do processo de insolvência".

xiii Artigo 52 do Código Civil: "Aplica-se às pessoas jurídicas, no que couber, a proteção dos direitos da personalidade".

Recebido em 03/10/2018

Publicado em 21/12/2018 